\title{
Pelatihan Manajemen Biaya Kepada Para Pengusaha Kecil dan Menengah Bidang Jasa Sebagai Strategi Strategi Mewujudkan Diferensiasi
}

\author{
Yunika Murdayanti \\ Universitas Negeri Jakarta, Indonesia, yunika_murdayanti@unj.ac.id \\ Etty Gurendrawati \\ Universitas Negeri Jakarta, Indonesia, egurendra@yahoo.com \\ Petrolis Nusa Perdana \\ Universitas Negeri Jakarta, Indonesia, Petrolis98@unj.ac.id
}

\begin{abstract}
Community service activity was conducted with the aim of providing skills for all smallscale entrepreneurs in the field of services or owners of the rented house. It was in order to be able to calculate the income of how much the number of rented houses they have, and depending on whether the rented house has been in accordance with the set of prices included the cost of electricity and water that every month must be paid by the rented house owner. Investment in a rented house is a simple investment, but it must be managed well. Long before you decided to invest in a rented house, it is good to do a survey first. The survey was conducted to find out the gaps and obstacles in managing the rented house business. Investment in a rented house needs management and a lot of time. Sometimes persistence is the key to good home rental management. This can be seen from the opportunities that exist in the investment of house rental is still promising. Participants were trained on tips on managing routine cost controls that occurred both during business and household expenses and trainees were able to understand how to smartly manage spending, payments, and other expenses so they would not find a larger expenditure rather than income.
\end{abstract}

Keywords: Cost Management, Differentiation, Small Scale Entrepreneur

\section{PENDAHULUAN}

Pada lingkungan bisnis dewasa

ini, pengembangan dan penggunaan informasi - khususnya informasi manajemen biaya - merupakan faktor kritis dalam manajemen yang efektif pada perusahaan dan organisasi.
Dengan melakukan pengelolaan informasi tersebut secara efektif dapat mengarahkan perusahaan kearah keberhasilan kompetitif. Sebagaimana lingkungan bisnis yang telah berubah, peran informasi manajemen telah berkembang pada semua fungsi

Available at

http://journal.unj.ac.id/unj/index.php/jpm 
manajemen. Informasi tersebut digunakan oleh para manajer untuk mengambil keputusan yang menguntungkan untuk perusahaannya.

Rumah kos adalah suatu bidang jasa kecil dan menengah yang merupakan usaha penyewaan kamar kos. Banyak hal yang menjadi pertimbangan memilih usaha kos sebagai alternatif berwirausaha. Kos atau kos-kosan merupakan suatu ladang bisnis yang mulai banyak diminati. Mulai dari kategori bisnis sampingan sampai dengan kategori bisnis serius. Dikatakan kategori bisnis sampingan, karena banyak menggunakan ruanganruangan sisa yang tidak terpakai dalam rumah atau rumah-rumah kosong yang tidak digunakan tapi memiliki nilai tinggi apabila dilakukan sebagai nilai usaha. Sedangkan kategori bisnis yang serius, para pengusaha ini memang menyediakan ruang khusus atau memiliki lahan untuk dijadikan rumah kos-kosan dan pengelolaannya juga dilakukan dengan serius serta professional.

Investasi dalam rumah kos-kos an merupakan investasi atau jenis usaha yang sederhana dan menjanjikan, Available at http://journal.unj.ac.id/unj/index.php/jpm apabila usaha tersebut dikelola secara baik. Jauh-jauh hari sebelum memutuskan untuk berinvestasi di rumah kos-kosan alangkah baiknya untuk melakukan survey terlebih dahulu baik survey financial dan nonfinansial. Survei ini dilakukan untuk mengetahui celah dan hambatan dalam mengelola usaha kos-kosan. Dalam mendesain sebuah sistem untuk investasi rumah kost-kostan memang akan memerlukan tenaga yang cukup besar. Investasi rumah kost-kostan perlu pengelolaan dan waktu yang banyak. Terkadang ketekunan inilah kunci dari pengelolaan kost-kostan yang baik. Ini dapat dilihat dari peluang yang ada pada investasi kost-kostan yang tetap menjanjikan. Semakin banyak fasilitas yang ditawarkan maka akan semakin menarik dan dilirik untuk ditempati oleh para calon penghuni rumah kos-kosan.

Alasan mengapa usaha rumah kost-kostan merupakan suatu jenis usaha yang menjanjikan diperkuat dengan adanya data mengenai jumlah penduduk di Indonesia yang semakin meningkat. Ditambah dengan penduduk miskin yang semakin meningkat jumlahnya baik didaerah perkotaan 
maupun pedesaan. Data dari Badan Pusat Statistik penduduk miskin di Indonesia pada tahun 2015 di bulan Maret (semester 1) mencapai 10.652,64 ribu orang dan di bulan September (semester 2) mencapai 10.619,89 ribu orang serta pada tahun 2016 di bulan Maret (semester 1) mencapai 10.339,79 ribu orang dan di bulan September (semester 2) mencapai 10.485,64 ribu orang. Maka dengan alasan ini bukan tidak mungkin banyak orang yang akan mencari rumah kontrakan untuk tempat berlindung dengan penghasilan yang pas-pasan.

Dibawah ini beberapa penyebab bisnis rumah kos bangkrut adalah:

Manajemen pengelolaan yang tidak tepat

Perlu dipikirkan bagaimana cara penghuni akan memasak, mencuci, menyetrika, menjemur, dan bagimana peraturan rumah kos dibuat agar aktifitas ditempat kos dapat berjalan secara tertib dan lancar.

\section{Penyewa tidak terlayani dengan baik}

Perlu pelayanan yang baik apabila penyewa membutuhkan bantuan, misalnya permintaan perbaikan pintu

Available at http://journal.unj.ac.id/unj/index.php/jpm yang rusak, permintaan duplikat kunci dll.

\section{Listrik atau air sering mati}

Listrik dan air bisa jadi kebutuhan pokok dalam menghuni rumah kos, jika keduanya sering mati maka penyewa akan berpikir untuk mencari alternative rumah kos lain yang lebih lancar.

\section{Bangunan tidak didesain dengan bagus}

Bangunannya juga perlu didesain sedemikian rupa agar nyaman, aman, dan indah. Contohnya area parkir motor yang mudah, adanya taman yang menyegarkan, sirkulasi udara bersih yang lancar serta hal-hal lainnya.

\section{Lingkungan tidak bersih}

Ini juga sangat mempengaruhi kenyamanan dalam bertempat tinggal, pengelolaan sampah perlu diatur secara khusus agar tidak berserakan atau bahkan baunya menggangu penyewa.

\section{Lingkungan tidak aman}

Jika perlu pengusaha rumah kos menyewa tenaga security khusus yang bertugas menjaga keamanan dan melayani keluhan-keluhan yang timbul.

Pembayaran uang sewa macet

Jika berangsur secara terus menerus maka pengusaha rumah kos bisa 
terganggu keuangannya sehinggs mempengaruhi pengelolaan rumah yang disewakan.

\section{Pusat keramaian didekat lokasi kos tutup}

Bisa jadi kampus, pusat perbelanjaan atau kantor tutup sehingga calon penyewa menjadi berkurang, namun kondisi ini jarang terjadi.

\section{Perumusan Masalah}

Berdasarkan analisis situasi di atas, dapat diidentifikasi rumusan masalah sebagai berikut:

1. Strategi apa yang digunakan oleh pengusaha rumah kos untuk bersaing dengan pengusaha rumah kos lainnya?

2. Bagaimana pengusaha rumah kos memahami pengelolaan dalam mengatur biaya untuk dapat menghasilkan suatu struktur modal keuangan yang baik?

3. Bagaimana pengusaha rumah kost memahami pengaturan pengeluaran rutin, pembayaran, belanja kebutuhan atau barang serta pengeluaran lainnya agar tidak mengalami lebih besar pasak daripada tiang?

Available at http://journal.unj.ac.id/unj/index.php/jpm
4. Bagaimana pengusaha rumah kost memahami kondisi lingkungan bisnis dewasa ini, yang memerlukan pengembangan dan penggunaan informasi - khususnya informasi manajemen biaya merupakan faktor kritis dalam manajemen yang efektif pada perusahaan dan organisasi agar menuju kearah keberhasilan kompetitif?

5. Bagaimana pengusaha rumah kos mampu melakukan perencanaan biaya dan perencanaan jangka pendek yang baik agar mampu bersaing dengan para kompetitor untuk mewujudkan strategi diferensiasi dengan meminimalkan biaya dan keunggulan yang bersaing ?

6. Bagaimana pengusaha rumah koskosan mampu mengatasi berbagai macam tips dan trik yang ditawarkan oleh bank maupun kompetitor sehingga mampu berpikir lebih rasional dan logis dalam membuat suatu keputusan yang berkaitan dengan pengelolaan biaya jasa?

\section{Tujuan dan Manfaat}


Pelatihan manajemen biaya pada para pengusaha kecil dan menengah bidang jasa sebagai strategi mewujudkan diferensiasi bertujuan:

1. Sebagai metode instrument salah satu teknik peningkatan manajerial kewirausahaan bagi para pengusaha kecil dan menengah bidang jasa rumah kos untuk dapat meningkatkan kapasistas dan kualitas penjualan jasanya;

2. Mengedepankan stratejik pengelolaan biaya yang berbasis investasi yang berkesinambungan untuk pengelolaan jangka panjang;

3. Sebagai wahana kewajiban Pengabdian bagi Masyarakat (PKM) bagi dosen.

\section{KAJIAN TEORITIK}

\section{Manajemen Biaya}

Menurut Blocher (2011) bahwa

Informasi manajemen biaya (cost management information) mencangkup informasi keuangan mengenai biaya dan pendapatan, dan informasi non keuangan mengenai rentensi pelanggan, prokdutivitas, kualitas, dan faktor-faktor penentuan utama kesuksesan lainnya bagi organisasi. Manajemen biaya (cost Available at http://journal.unj.ac.id/unj/index.php/jpm management) adalah pengembangan dan penggunaan dari informasi manajemen biaya. Akuntansi manajemen (management accounting) adalah suatu profesi yang melibatkan kemitraan dalam pengambilan keputusan manajemen, menyusun perencanaan dan sistem manjemen kinerja, serta menyediakan keahlian dalam pelaporan keuangan dan pengendalian untuk membantu manajemen dalam memformulasikan dan mengimplementasikan suatu strategi organsasi.

\section{Strategi Kompetitif}

Dalam mengembangkan posisi kompetitif yang berkesinambungan, setiap entitas usaha secara sengaja atau sebagai akibat tekanan pasar akan mencapai satu atau dua strategi kompetitif yaitu (Blocher, 2011):

1. Kepemimpinan Biaya (cost leadership)

Adalah strategi strategi dalam hal ini perusahaan mengungguli kompetitor dalam menghasilkan produk atau jasa dengan biaya yang paling rendah. Pemimpin biaya menghasilkan laba secara berkesinambungan pada tingkat harga yang lebih rendah, 
sehingga membatasi pertumbuhan kompetisi dalam industri melalui kesuksesannya dalam mengurangi harga dan merusak profitabilitas competitor, yang harus mengikuti harga redah pemimpin biaya tersebut. Pemimpin biaya umumnya mempunyai pangsa pasar yang relatif besar dan cenderung menghindari pasar ceruk (niche market) atau segmen pasar dengan menggunakan keunggulan harga nyademi mendapatkan bagain yang besar dari pasar yang luas. Ketika sebagian besar perusahaan berupaya keras mengurangi biaya, pemimpin biaya dapat berfokus hampir sepenuh nya pada penurunan biaya, sehingga dapat memastikan kepemimpinan biaya dan harga secara signifikan di pasar.

Kelemahan potensial dari strategi kepemimpinan biaya adalah cenderungan memotong biaya yang dapat menjatuhkan permintaan terhadap produk atau jasa, contohnya dengan menghilangkan fitur-fitur penting. Pemimpin biaya akan tetap berkompetisi hanya jika konsumen melihat bahwa produk atau jasa yang dihasilkannya sama (minimal

Available at http://journal.unj.ac.id/unj/index.php/jpm mendekati) dengan produk kompetitor yang harganya lebih tinggi.

2. Diferensiasi

Strategi diferensiasi (differentiation) diimplementasikan dengan cara menciptakan produk atau jasa yang unik dengan cara tertentu, biasanya memiliki kualitas yang lebih baik, fitur produk jasa pelanggan, atau inovasi. Kadang-kadang strategi diferensiasi disebut dengan kepemimpinan produk yang mengacu pada inovasi dan fitur dalam produk . Dalam kasus lain, strategi mungkin disebut dengan strategi berfokus pada pelanggan atau solusi bagi pelanggan, untuk menunjukan bahwa organisasi telah sukses pada beberapa dimensi layanan pelanggan. Persepsi ini menyebabkan perusahaan dapat mematok harga lebih tinggi dan mengungguli kompetisi laba tanpa menurunkan biaya secara signifikan. Sebagian besar industri, termasuk industri elektronik dan pakaian, memiliki perusahaan-perusahaan yang terdiferensiasi. Kebutuhan akan diferensiasi khususnya terjadi pada lini pruduk dalam hal ini persepsi akan kualitas dan citra adalah penting, 
seperti misalnya komestik, perhiasan, dan mobil.

Kelemahan strategi diferensiasi terletak pada kecendrungan perusahaan untuk meruasak kekuatannya dengan berusaha menurunkan biaya atau mengabaikan perlunya memiliki rencana pemasaran yang terus-menerus dan agresif untuk menekankan diferensiasi. Jika pelanggan mulai yakin bahwa perbedaannya dengan produk kompetitor tidak lagi signifikan, maka produk kompetitor yang biayanya lebih rendah akan lebih menarik.

\section{Pengertian Rumah Kost}

Pengertian kos atau sering disebut kos-kosan adalah sejenis kamar sewa yang disewa (booking) selama kurun waktu tertentu sesuai dengan perjanjian pemilik kamar dan harga yang disepakati. Umumnya booking kamar dilakukan selama kurun waktu satu tahun. Namun demikian ada pula yang hanya menyewakan selama satu bulan, tiga bulan, dan enam bulan, sehingga sebutannya menjadi sewa tahunan, bulanan, tribulanan, dan tengah tahunan. Penyewaan yang kurang dari waktu itu mahasiswa lebih memilih di penginapan. Berbeda dengan Available at http://journal.unj.ac.id/unj/index.php/jpm kos-kosan, rumah kontrakan merupakan bentuk satu rumah sewa yang disewakan kepada masyarakat khususnya bagi para pelajar dan mahasiswa yang bertempat tinggal di sekitar kampus, selama kurun waktu tertentu sesuai dengan perjanjian sewa dan harga yang disepakati (Pramudi, 2009).

Mendengar kata kos, setiap orang mempunyai kesamaaan pengertian bahwa sebuat tempat atau sebuah kamar yang disewakan kepada seseorang yang membutuhkan dalam jangka waktu tertentu dan biaya sewa yang telah ditentukan. Meruntut sejarahnya kata kost berasal dari kata belanda yaitu in de kost, yang artinya makan didalam, dalam pengertian yang lebih luas tinggal dan ikut makan dalam rumah tempat menumpang tinggal.

Pada prinsipnya fungsi koskosan merupakan: (1) sarana tempat tinggal sementara bagi mahasiswa yang pada umumnya berasal dari luar daerah selama masa studinya, (2) sarana tempat tinggal sementara bagi masyarakat umum yang bekerja dikantor atau yang tidak memiliki rumah tinggal agar berdekatan dengan lokasi kerja, (3) 
sarana latihan pembentukan kepribadian mahasiswa untuk lebih berdisplin, mandiri dan bertanggung jawab karena jauh dari keluarga, (4)tempat untuk menggalang pertemanan dengan mahasiswa lain dan hubungan sosial dengan lingkungan sekitarnya.

\section{MATERI DAN METODE}

\section{Kerangka Pemecahan Masalah}

Kerangka atau tahapan kegiatan Pemahaman Manajemen Biaya pada para pengusaha kecil dan menengah bidang jasa sebagai strategi mewujudkan diferensiasi adalah sebagai berikut:

\section{Analisis Kebutuhan}

Berdasarkan diskusi yang dilakukan oleh tim pelaksana pengabdian masyarakat memerlukan program pelatihan ini karena:

a. Kurangnya pemahaman dalam pengelolaan biaya para pengusaha kecil menengah bidang jasa rumah kost-kostan sehingga tidak dapat menghasilkan suatu struktur modal keuangan yang baik.

b. Kurangnya pemahaman cara cerdas mengatur pembelanjaan, pembayaran, dan pengeluaran Available at http://journal.unj.ac.id/unj/index.php/jpm lainnya agar tidak mengalami lebih besar pasak daripada tiang

c. Kurangnya pemahaman dalam melakukan perencanaan keuangan yang mempunyai kecerdasan dalam mengelola pendapatan (uang) dan sangat penting bagi semua orang, tak terkecuali golongan ekonomi menengah ke bawah agar mereka mampu meningkatkan taraf hidupnya.

d. Kurangnya pemahaman mengenai manajemen sederhana dalam mengelola usaha rumah kos, dalam hal ini pemilik dari rumah kontrakan mampu menghitung pendapatnya dari berapa banyak jumlah rumah kontrakan yang ia miliki, serta membandingkan biaya listrik, air dan biaya lainnya. Dengan kata lain, memiliki jumlah yang diterima para pengusaha rumah kontrakan adalah pendapatan dari jumlah rumah kos yang dimiliki dikurangi dengan biaya listrik dan air setiap bulan yang harus dibayar oleh pemilik rumah kos.

e. Banyaknya tawaran pinjaman di lingkungan masyarakat yang 
mengakibatkan terjebak oleh berbagai macam trik baik yang ditawarkan oleh bank maupun tengkulak sehingga tidak dapat berpikir secara rasional dan logis dalam membuat suatu keputusan yang berkaitan dengan pengelolaan keuangannya.

Berdasarkan permasalah diatas, maka secara singkat, pemecahan masalah dapat dilihat pada diagram dibawah:

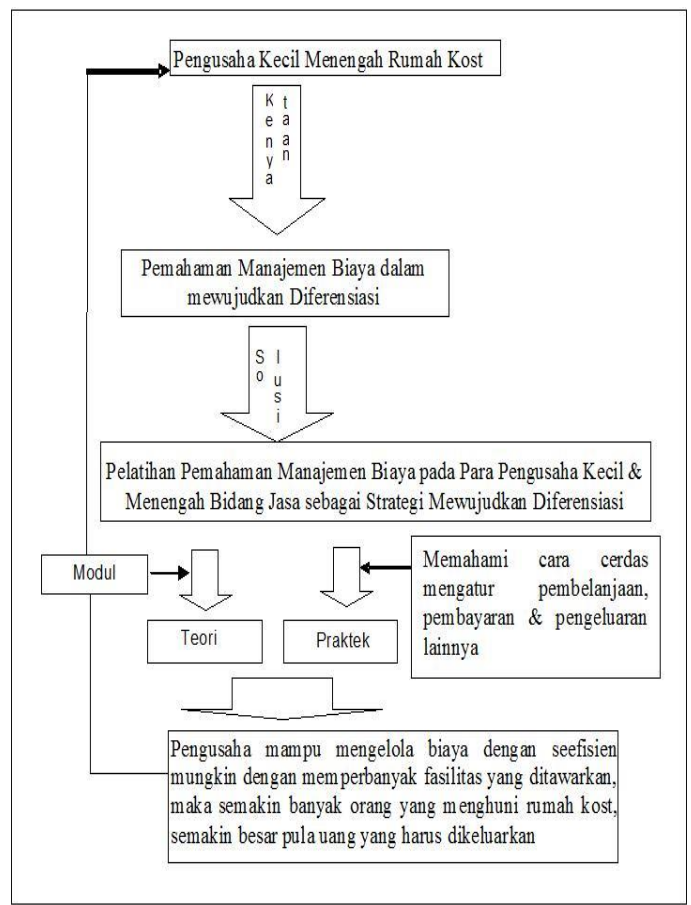

Gambar 1. Kerangka Pemecahan Masalah

\section{Rancangan Instruksional}

Available at http://journal.unj.ac.id/unj/index.php/jpm
Dalam menentukan rancangan instruksional ini perlu dipertimbankan aspek-aspek berikut:

a. Isi materi program pelatihan yang relevan dengan kebutuhan peserta. Tim pelaksanaan telah menetapkan kebutuhan materi bagi para pengusaha kecil menengah rumah kos-kosan.

b. Modul praktik diperoleh dari nara sumber mengenai materi manajemen biaya yang digunakan pada pelatihan ini untuk membantu para para pengusaha kecil menengah rumah kos-kosan memahami manajemen biaya yang efisien sehingga tercapai keunggulan bersaing.

\section{Tahap Pengembangan}

Tim pelaksana pengabdian masyarakat berupaya mengembangkan pelatihan ini baik dalam hal materi pelatihan, modul, dan tanya jawab dalam bentuk yang relevan dengan aspek manaejmen biaya dalam pengembangan program pelatihan pemahaman manajemen biaya pada para pengusaha kecil dan menengah bidang jasa sebagai strategi mewujudkan diferensiasi. 


\section{Realisasi Pemecahan Masalah}

\section{Persiapan Kegiatan}

Berikut persiapan yang dilakukan tim pelaksana pengabdian masyarakat sebelum kegiatan ini dilakukan:

a) Melakukan studi pustaka tentang Pemahaman Manajemen Biaya pada Para Pengusaha Kecil dan Menengah Bidang Jasa sebagai Strategi Mewujudkan Diferensiasi.

b) Melakukan observasi dan pendataan calon peserta kegiatan pelatihan ini.

c) Mempersiapkan materi, yaitu pembuatan powerpoint atau media pelatihan lainnya yang akan disajikan kepada peserta.

d) Menentukan waktu pelaksanaan dan lamanya kegiatan pengabdian masyarakat.

\section{Pelaksanaan Kegiatan}

Kegiatan pengabdian masyarakat ini akan dilakukan di daerah Rawamangun Jakarta Timur dengan para peserta pengusaha rumah kostkostan.

\section{Materi Pelatihan dan Instruktur}

Available at http://journal.unj.ac.id/unj/index.php/jpm
Materi
melatihan ini memahami mengenai manajemen biaya yaitu pengelolaan biaya seefisien mungkin namun mampu menghasilkan keunggulan bersaing dibandingkan para kompetitornya.

\section{Rancangan Evaluasi}

Indikator yang digunakan dalam pencapaian tujuan atau tolak ukur yang digunakan untuk menyatakan keberhasilan adalah :

1. Mampu membuat pengelolaan biayanya dan pendapatannya sendiri sehingga dapat menghasilkan suatu struktur modal keuangan yang baik.

2. Mampu mengerjakan keuangan pribadinya dengan antusias dan perasaan yang bahagia yang berakibat pada peningkatan taraf hidup keluarga.

3. Mampu mengelola sumber daya baik di dalam dirinya sendiri maupun diluar dirinya untuk menghasilkan suatu nilai yang dalam hal ini diukur dengan uang.

4. Mampu bersikap hati-hati dengan utang. Penjelasannya adalah caranya ketahui kapan sebaiknya 
berutang dan kapan tidak berutang dengan mampu menguasai tip yang diperlukan jika ingin mengambil utang atau membeli barang secara kredit.

5. Mampu menjalani manajemen biaya yang baik sehingga menghasilkan usaha yang jauh lebih efisien dibandingkan sebelumnya serta membuat perencanaan strategis dengan baik.

\section{Khalayak Sasaran yang Strategis}

Anggota khalayak yang dianggap strategis untuk dilibatkan adalah para pengusaha kecil dan menengah bidang jasa yaitu pengusaha rumah kos-kosan di daerah sekitar Rawamangun, Jakarta yang berjumlah 17 peserta.

\section{Metode Penerapan IPTEKS}

Metode kegiatan yang digunakan adalah :

1. Wawancara dengan pemilik rumah kost yang memiliki kesulitan dalam pengelolaan biaya yang kurang terkontrol tetapi mempunyai kemampuan jiwa berwirausaha yang kuat.

2. Ceramah mengenai manajemen biaya pada para pengusaha kecil dan Available at http://journal.unj.ac.id/unj/index.php/jpm menengah bidang jasa sebagai strategi mewujudkan diferensiasi serta manfaatnya bagi para pengusaha rumah kos.

3. Pengenalan konsep pemahaman manajemen biaya pada para pengusaha kecil dan menengah bidang jasa sebagai strategi mewujudkan diferensiasi yang baik secara mendalam kepada para pengusaha rumah kos melalui presentasi makalah dan kasus-kasus yang up to date.

4. Mengadakan diskusi untuk dapat menghasilkan timbal balik mengenai pemahaman manajemen biaya pada para pengusaha kecil dan menengah bidang jasa sebagai strategi mewujudkan diferensiasi.

\section{HASILDAN PEMBAHASAN}

\section{Deskripsi Kegiatan}

Kegiatan pelatihan manajemen biaya pada para pengusaha kecil dan menengah bidang jasa sebagai strategi mewujudkan diferensiasi ini dilaksanakan dengan jumlah peserta pelatihan seluruhnya 17 orang, terdiri dari para pengusaha kos-kosan dan pedagang yang berada di wilayah 
rawamangun Jakarta Timur.

Pelaksanaan pelatihan tersebut berjalan lancar, hal ini dikarenakan partisipasi dan keterkaitan semua pihak.

Kegiatan ini dilaksanakan hari Sabtu, 20 Mei 2017 dari jam 09.00 sampai dengan 13.00 WIB. Pelatihan ini ditekankan pada keberhasilan peserta dalam menyerap materi khususnya bertujuan pada para pengusaha agar tidak terjerat dengan pengeluaran yang banyak serta kiat-kiat dalam memperoleh tambahan diluar gaji bulanan, mandiri secara finansial dengan menggunakan penghasilannya, dapat menciptakan keunggulan kompetitif guna mencapai kesejahteraan dan peningkatan taraf hidup para pengusaha jasa, mampu mengelola usaha rumah kost, dalam hal ini pemilik dari rumah kontrakan mampu menghitung pendapatnya dari berapa banyak jumlah rumah kontrakan yang ia miliki, serta membandingkan biaya listrik, air dan biaya lainnya. Dengan kata lain, memiliki jumlah yang diterima para pengusaha rumah kontrakan adalah pendapatan dari jumlah rumah kost yang dimiliki dikurangi dengan biaya listrik dan air Available at http://journal.unj.ac.id/unj/index.php/jpm setiap bulan yang harus dibayar oleh pemilik rumah kost. Kegiatan diatas dilakukan melalui diskusi secara interaktif dengan memberikan souvenir untuk memancing keaktifan peserta dalam kegiatan ini.

Materi pelatihan disampaikan dalam bentuk arahan praktis yang dapat menunjang kemampuan mereka meningkatkan taraf hidupnya dan mempunyai keahlian dalam mengembangkan usahanya serta mampu memiliki daya saing yang tinggi dalam industri perekonomian. Pendekatan dilakukan dengan cara melakukan wawancara dengan pemilik rumah kost yang memiliki kesulitan dalam pengelolaan biaya yang kurang terkontrol tetapi mempunyai kemampuan jiwa berwirausaha yang kuat serta ceramah dan diskusi mengenai pemahaman manajemen biaya pada para pengusaha kecil dan menengah bidang jasa sebagai strategi mewujudkan diferensiasi serta manfaatnya bagi para pengusaha rumah kost.

\section{Analisis Teoretis}

Pelaksanaan pelatihan ini tidak dapat dicapai jika tidak dapat dukungan 
dari para pengusaha kecil dan menengah di sekitar lingkungan daerah rawamangun Jakarta Timur. Ada kecenderungan memandang materi pelatihan hanya sebagai retorika belaka, untuk itu diperlukan strategi penyelenggaraannya. Cara yang dipakai adalah dengan melakukan pendekatan kepada para peserta sebagai orang yang langsung berkaitan dengan permasalahan.

Dalam mengupayakan materi pelatihan ini dapat dipahami dengan baik maka tim memilih metode pemberian materi dilanjutkan sesi praktek, tanya jawab, sharing, sesi diskusi oleh peserta. Pengetahuan akan materi pengenalan konsep manajemen biaya pada para pengusaha kecil dan menengah bidang jasa sebagai strategi mewujudkan diferensiasi yang baik secara mendalam kepada para pengusaha rumah kos adalah dengan memberikan presentasi makalah dan kasus-kasus yang up to date, serta diskusi untuk dapat menghasilkan timbal balik mengenai pada Para Pengusaha Kecil dan Menengah Bidang Jasa ini.

Available at http://journal.unj.ac.id/unj/index.php/jpm
Dengan media power point dan video kasus terkini, dibahas tuntas mengenai contoh seorang pengusaha yang sukses menjalan usahanya dan memiliki berbagai macam produk dan cabang usahanya. Pembahasan tersebut dilengkapi dengan contoh-contoh yang relevan dan trik-trik yang harus diperhatikan agar mampu menghasilkan keunggulan kompetitif dalam berkompetisi dengan para pengusaha lainnya.

Pembahasan media komunikasi langsung disajikan sebagai materi kedua dan penutup dalam sesi pengabdian masyarakat ini. Pada sesi kedua ini, lebih banya memberikan tips dan trik melakukan efisiensi biaya dan cara menciptakan produk yang inovatif. Penyajian materi dilakukan lengkap dengan praktek dan contoh kasus yang terkini sehingga mampu membuat pengelolaan biayanya dan pendapatannya sendiri untuk dapat menghasilkan suatu struktur modal keuangan yang baik dan mengerjakan keuangan pribadinya dengan antusias dan perasaan yang bahagia yang berakibat pada peningkatan taraf hidup keluarga. 


\section{Evaluasi kegiatan}

Pada proses pelaksanaan pengabdian masyarakat, kami mendapatkan apresiasi positif dari para pengusaha kecil dan menengah bidang jasa ini. Antusiasme peserta sangat tinggi dalam merespon pemberian materi yang dibuktikan dengan munculnya berbagai pertanyaan yang bervariasi seputar topic manajemen biaya para pengusaha kecil dan menengah ini, yang menyebabkan waktu penyelenggaraan sedikit lebih lama dari yang dijadwalkan. Tips dan triks yang dipraktekkan memang menjadi kekuatan tersendiri dalam pembahasan manajemen biaya dalam menciptakan keunggulan bersaing yang mampu meningkatkan pendapatan usahanya.

\section{KESIMPULAN DAN SARAN}

\section{Kesimpulan}

Rumah kos-kosan yang memiliki lokasi yang sangat strategi dapat menjadi alternatif pilihan bagi para mahasiswa khususnya dan masyarakat umumnya sebagai tempat tinggal. Usaha kost-kostan yang memiliki tempat dekat kampus, tempat makan, warnet, fotokopi, dan tempatAvailable at http://journal.unj.ac.id/unj/index.php/jpm tempat hiburan lainnya akan menjadi pilihan favorit bagi para calon penghuni rumah kost-kostan. Biasanya bagi para pemilik rumah kos-kosan yang memiliki tempat usaha strategis akan membuat investasi berjalan lancar, terlebih lagi modal yang dikeluarkan akan lebih cepat kembali dari investasi apapun. Ada yang memilih kos dengan lingkungan yang mendukung dan kondusif untuk belajar atau ada juga yang lebih suka keramaian. Selain itu harga sewa dan fasilitas kos juga menjadi pertimbangan mahasiswa dalam memilih rumah kos. Memahami kemampuan dengan cerdas mengatur belanja rutin operasional kos-kosan, pembayaran, dan pengeluaran lainnya agar tidak mengalami lebih besar pasak daripada tiang. Namun dengan melakukan pelatihan manajemen biaya ini menambah wawasan para pengusaha kecil dan menengah bidang jasa ini untuk mampu mengelola informasi keuangannya tersebut secara efektif agar dapat menuju kearah keberhasilan kompetitif serta memaksimalkan perencanaan biaya dan perencanaan jangka pendek dengan baik untuk dapat bersaing dengan para kompetitor dalam 
mewujudkan strategi diferensiasi yaitu mampu meminimalkan biaya dengan keunggulan yang bersaing dan yang paling penting adalah para pengusaha tersebut tidak akan terjebak oleh berbagai macam trik yang merugikan secara keuangan yang ditawarkan oleh para pelaku bisnis lainnya melainkan dapat berpikir lebih rasional dan logis dalam membuat suatu keputusan yang berkaitan dengan pengelolaan biaya jasa.

\section{Kegiatan}

pengabdian masyarakat yang telah dillakukan ini telah membuktikan mampu memberikan pencerahan dalam mempersiapkan para pengusaha kecil dan menengah bidang jasa ini. Hasil yang dicapai bahwa dalam kegiatan pelatihan manajemen biaya ini adalah para pengusaha kecil dan menengah bidang jasa tersebut merasa puas dan senang terhadap kegiatan pelatihan tersebut, terbukti pada saat pelatihan dilaksakana terlihat ketekunan dalam mengikuti kegiatan pelatihan tersebut sampai selesai dengan respon dan suasana yang dinamis. Pada pelaksanaan sesi tanya jawab terlihat kemampuan peserta lebih tereksplorasi dengan baik dilihat dari Available at http://journal.unj.ac.id/unj/index.php/jpm antusiasme peserta dan banyaknya pertanyaan. Oleh karena itu dapat disimpulkan bahwa kegiatan ini sangat diminati para pengusaha tersebut, bahkan ada yang mengusulkan untuk dapat dilaksanakan kegiatan lanjutan.

\section{Saran}

Kegiatan ini harus dikembangkan lagi dan diupayakan untuk kerja sama yang lebih bervariasi lagi dengan para pengusaha kecil dan menengah bidang jasa ini. Pada pengabdian kali ini mengangkat tema manajemen biaya, dalam hal ini kami menyarankan kepada para pengusaha kecil dan menengah untuk dapat membuat strategi yang didesain dalam mengidentifikasian peluang-peluang bisnis yang ada, perencanaan strategi, dan membuat keputusan operasional. Diharapkan dengan pelatihan ini dapat menjadi bahan masukan bagi para pembaca mengenai pemahaman manajemen biaya pada para pengusaha kecil menengah bidang jasa dalam membuat strategi cost leadership serta keunggulan kompetitif, kiat-kiat membuat perencanaan biaya yang baik dan dapat memanfaatkan peluang kredit 
melalui utang jika diperlukan secara optimal.

\section{DAFTAR PUSTAKA}

Bloucher, Edward J. David E. Stout, and Garys Cokins. 2011. Manajemen Biaya: Penekanan Strategis. Edisi ke-5. Jakarta: Penerbit Salemba Empat.

Hajar, Sitti. Made Susilawati, dan D.P.E. Nilakusmawati. FaktorFaktor Yang Memengaruhi Keputusan Mahasiswa Dalam Memilih Rumah Kost. e-Jurnal Matematika. Vol. 1 No. 1 Agustus 2012, 25-31.

Resmi, Ni Nyoman dan Ni Ketut Adi Mekarsari. 2011. Faktor-Faktor Yang Mempengaruhi Perilaku Anak Kos Dalam Pemilihan Rumah Pemondokan Di Kota Singaraja. WIDYATECH Jurnal Sains dan Teknologi. Vol. 11 No. 1. 79-90.

Utomo, Pramudi. 2009. Dinamika pelajar dan mahasiswa di sekitar kampus Yogyakarta (Telaah Pengelolaan rumah kontrak dan rumah sewa). International symposium on management of student dormitory. Yogyakarta: Universitas Negeri Yogyakarta.

Robbins, Stephen P. and Mary Coulter. 2007. Manajemen. Edisi 1 dan 2. Jakarta: Penerbit Indeks.

Available at http://journal.unj.ac.id/unj/index.php/jpm
Sugianto, Herik. Yulianti dan Hengky Anra. 2016. Sistem Pendukung Keputusan Pemilihan Tempat Kost Khusus Mahasiswa dengan Metode AHP dan TOPSIS Berbasis Web (Studi Kasus: Kota Pontianak). Jurnal Sistem dan Teknologi Informasi (JUSTIN). Vol. 1, No. 1. 1-6.

Sukadi, Fery Setyawan. 2014. Sistem Pembayaran Biaya Kost Terkomputerisasi Pada Rumah Kost Griya Ampel Muda Kabupaten Pacitan. Indonesian Journal on Networking and Security. Vol.3 No.1. 1-9.

http://www.informasikost.com/tipsmengelola-tempat-kost-danmengatur keuangannya/ diakses pada tanggal 30 Januari 2017

http://www.rumah.com/beritaproperti/2012/8/1631/kelebihandan-kekurangan-bisnis-rumah-kos diakses pada tanggal 30 Januari 2017

https://www.bps.go.id/linkTableDinami s/view/id/1119 diakses pada tanggal 30 Januari 2017

http://bisnis.sewakost.com/menentukanharga-sewa-kost/ diakses pada tanggal 30 Januari 2017

http://dpgpjakarta.com/index.php/data/ rumah-kost diakses pada tanggal $30 \quad$ Januari 2017 